\title{
Effects of nitrogen and micronutrients on the growth of safflower under limited water conditions in a high-elevation region
}

\section{Mostafa Fattahi,}

\section{Mohsen Janmohammadi*,}

Shahriar Dashti,

\section{Mojtaba Nouraein,}

\section{Naser Sabaghnia}

Faculty of Agriculture, Department of Agronomy and Plant Breeding, University of Maragheh, Maragheh, P.O. Box 55181-83111, Iran
Beneficial nanoparticles are at the leading edge of the rapidly developing field of nanotechnology. Nanotechnology applied to nanofertilizers could play a fundamental role in improving the availability of plant nutrients under unfavourable environmental conditions. To evaluate the effects of different levels of nitrogen fertilizer $\left(0,75\right.$, and $\left.150 \mathrm{~kg} \mathrm{ha}^{-1}\right)$ and nanostructured micronutrients $(\mathrm{Zn}, \mathrm{Fe}, \mathrm{Cu})$ on the seed yield of spring safflower, a study was carried out in the highland region of Baneh, Iran. Specific objectives were to assess the effects of combined application of nano-chelated micronutrients and nitrogen on safflower under rainfed conditions. Assessments of morphological traits revealed that application of nitrogen at the rate of $75 \mathrm{~kg} \mathrm{ha}^{-1}$ significantly increased the plant height, canopy spread, stem diameter, and plant dry weight. Also, ground cover, canopy spread, capitulum diameter, and the number of the secondary branches were considerably affected by nano-chelated micronutrients, so the highest values were observed in the plants grown with the application of zinc and copper. Results showed that the effects of interaction of nitrogen and micronutrients were significant for the biological yield, seed number, 1000-seed weight, the percentage of unfilled seeds, and seed yield. A comparison of combined treatments showed that the best performance was recorded for plants grown with the application of $\mathrm{N}_{0}-\mathrm{Zn}, \mathrm{N}_{75}-\mathrm{Zn}$, and $\mathrm{N}_{150}-\mathrm{Cu}$. The results of the present experiment agreed with the conclusion that utilization of nitrogen may affect the efficiency of micronutrients. Altogether, the results suggested that the application of intermediate levels of nitrogen fertilizers along with nano-chelated $\mathrm{Zn}$ can improve safflower production under rainfed condition.

Keywords: crop productivity, dryland conditions, nano active ingredients, nanostructured fertilizers, nutrient interaction

\footnotetext{
"Corresponding author. Email: jmohamad@alumni.ut.ac.ir
} 


\section{INTRODUCTION}

Mountainous and highland areas have significant roles in crop production and enhancement of food security in many countries of the world. Highlands are the areas with altitude of more than 800 metres above sea level and rugged land with cool to extremely cold winter. Agriculture in these regions is mainly based on rainfed production system with winter cereals as the main crops, as well as drought-resistant oil crop (Roozitalab et al., 2011). Food security in a highland semi-arid region is generally influenced by water and nutrient management. The precipitation is the most important environmental factor limiting agricultural activities in semi-arid regions (Tilahun, 2006). The amount and pattern of precipitation are among the most important factors that affect productivity of agricultural systems. In the Mediterranean semiarid region, most of the rainfall occurs during the winter and precipitation is often low and erratic in the beginning and towards the end of the growing season. Under these conditions, crops are subjected to drought stress in both seeding and terminal growth stages, which causes a considerable decrease in crop production (Singh, Matsui, 2002). Nevertheless, it is worth knowing how long a wet spell is likely to persist, and what the probabilities of experiencing dry spells of various durations at critical times during the growing season are (Mzezewa et al., 2010).

Likewise, it seems that soil moisture status may significantly affect the nutrient availability and plant nutrition. It has been recognized that micronutrient deficiencies are widespread in Mediterranean semi-arid regions, and the soils in these areas are deficient in major and essential elements such as nitrogen and phosphorus and some micronutrients, but they are generally well supplied with potassium and both calcium and magnesium (Ryan, 2010). Micronutrients are nutrients required by plants throughout life in small quantities to organize a range of physiological processes. While micronutrients are required in relatively smaller quantities for plant growth, they are as important as macro- nutrients and play imperative roles in plants growth (Marschner, 2012).

This is despite the fact that intensive crop rotation and imbalanced fertilizer use have exacerbated micronutrient deficiency in this area. Meanwhile, semi-arid regions have not benefited from the "green revolution" as much as the areas with high rainfall (FAO, 1998). Besides, the full potential yield of crop plants can only be achieved by application of unlimited amounts of water, fertilizers, and usually large inputs of pesticides. All the above-mentioned referred to serious nutritional problems in semi-arid areas. Due to the poor condition of the soil, crop responses to conventional fertilizers have generally been low and imperceptible in these areas (Reynolds et al., 2009). Erratic rainfall in the semi-arid region makes agricultural productivity less predictable, while serious concerns about the environment highlight the need of producing more efficient micronutrient fertilizers.

However, in Mediterranean semi-arid areas safflower (Carthamus tinctorius L.) is considered one of the most important crops (Yau, 2007). Safflower is a highly branched, herbaceous, thistlelike annual plant. It is commercially cultivated for the oil extracted from the seeds. The flowers from the spiny cultivars are grown for oil, while some spineless cultivars are used for dye production (FAO, 2015). The oilseed crop safflower (Carthamus tinctorius) is believed to have been domesticated in the Fertile Crescent. Overall, the NearEastern origin of safflower was confirmed on the basis of previous researches (Singh, Nimbkar, 2006). Safflower can be grown in dryland areas at altitudes ranging from below 1000 metres to 2300 metres above sea level (Haghighati Malek, Ferri, 2014). In 2013, global production of safflower seeds was 718,161 tonnes, with Kazakhstan accounting for $24 \%$ of the total. Other significant producers were India, the United States, Mexico, and Argentina (FAOSTAT, 2013). However, safflower is a drought-tolerant plant. Introduction of safflower as a drought resistant crop is mainly based on its ability to draw water from a depth of up to $3.5 \mathrm{~m}$ (Yau, 2007). Although the rooting system of safflower is 
extensive and in deep soils roots, it requires a fertile, fairly deep and well-drained soil (FAO, 2015). Hence, nutrient management in safflower production system is a crucial issue, and deficiencies in some elements such as nitrogen, zinc, iron, and manganese are very prevalent (Kumar, Sharma 2013). Balanced crop nutrition supplying all essential nutrients is a cost-effective management strategy.

It appears that nanotechnology has a potential to provide solutions to fundamental agricultural problems caused by conventional fertilizer management (Mastronardi et al., 2015). Nanotechnology is the application of beneficial particles at the atomic or molecular level, usually at scales $<100 \mathrm{~nm}$. In recent years, research into nanofertilizers has increased. Nanofertilizers can be more soluble or more reactive than conventional fertilizers (DeRosa et al., 2010; Dimkpa, Bindraban 2016; Monreal et al., 2015; Subramanian et al., 2015). Utilization of nanofertilizers can improve solubility and dispersion of insoluble nutrients in soil, reduce nutrient immobilization (soil fixation), and increase bio-availability (Naderi, DaneshShahraki, 2013). Although there are numerous examples of the positive effects of application of micronutrients to crop growing (Ryan, 2010; Janmohammadi et al., 2015; Dimkpa, Bindraban, 2016), information about nanostructured micronutrient fertilizers and their interaction with macronutrients application is not sufficient. The evaluation of the exact effects of applying micronutrients nanofertilizers alone or in combination with nitrogen to safflower crops in semi-arid region need to be better established. The present investigation was undertaken to improve the understanding about the interaction of nano-chelated iron, zinc, and copper fertilizers with different level of nitrogen fertilizer on the yield and yield components of spring safflower in a semi-arid, high-elevation Mediterranean environment.

\section{MATERIALS AND METHODS}

A field experiment was conducted during the growing season of $2015 / 16$ at a farmer's field in Dousineh, Baneh region. Baneh is located in north-western province of Kurdistan in the west of Iran. The field is located at $45^{\circ} 53^{\prime}$ East longitude and $35^{\circ} 59^{\prime}$ North latitude, at an altitude of 1610 metres above sea level. The climate of Baneh is temperate. The winter months are much rainier than the summer months in Baneh. According to Köppen-Geiger climate classification, the climate of this region is $\mathrm{BS}$ (cold semi-arid Steppe). The average annual temperature is $12.2^{\circ} \mathrm{C}$ in Baneh. Mean annual rainfall in the area is $714 \mathrm{~mm}$ (mean value for a 30 -year period, 1984-2014), but there is a high interannual variability with the occurrence of dry and wet years. The 2011/2012 agricultural year (from September 2011 to August 2012) was a dry one, with only $341 \mathrm{~mm}$ of rainfall, while the 2013/2014 agricultural year was a very wet year, with $724 \mathrm{~mm}$ of rainfall. Normally, during the spring-sown chickpea crop cycle, the amount of rainfall is usually very low. The precipitation was $105.7 \mathrm{~mm}$ during the cropping season. The soil of experimental site is sandy clay loam, with $\mathrm{pH} 7.4$, low in organic carbon $(0.51 \%)$, total nitrogen $0.26 \%, \mathrm{CaCo}_{3} 17 \%$, electrical conductivity (EC) $6.15 \mathrm{ds} \mathrm{m}^{-1}$, iron $1.58 \mathrm{ppm}$, manganese 7.09 ppm, copper $0.66 \mathrm{ppm}$, zinc $0.78 \mathrm{ppm}$ and potassium $642 \mathrm{ppm}$.

The experimental field was ploughed twice: in early autumn and two weeks before planting, subsequently soil was harrowed twice to bring the soil to fine tilth. After the second primary tillage operation, well-rotten farmyard manure was applied as per the treatment and thoroughly mixed into the top soil. After opening of furrows, the seeds were hand planted on 19 April, 2015. The spring safflower (Carthamus tinctorius L.) cv. 'Goldasht' was used in the experiment. The experimental design was a split plot with three replicates. Main treatments were assigned to nitrogen fertilizer $\left(0,75,150 \mathrm{~kg} \mathrm{ha}^{-1}\right)$ and sub-plots allocated to the nano-chelated micronutrients $(\mathrm{Zn}, \mathrm{Fe}, \mathrm{Cu})$. Each plot was $4 \mathrm{~m}^{2}$ consisting of eight rows, $2 \mathrm{~m}$ long and $25 \mathrm{~cm}$ apart. Seeds were sown $4 \mathrm{~cm}$ apart at $5 \mathrm{~cm}$ depth. After the emergence, the seedlings were thinned manually to achieve optimum plant density. Weeds were frequently controlled 
manually, prior to capitulum emergence. Metal oxide nanoparticles were formulated as chelated form in nano-fertilizers. Nanoparticles have a large surface area, sorption capacity, and controlled release. They can accurately release their active ingredients in response to environmental triggers such as moisture or temperature fluctuations and biological demands. Nanoparticles of metal oxides (nano- $\mathrm{ZnO}$, nano- $\mathrm{Fe}_{2} \mathrm{O}_{3}$, nano- $\mathrm{CuO}$ ) were applied for the synthesis of nanofertilizers. The chelate metal-ethylenediamine di(o-hydroxy-phenylacetic acid) (metalEDDHA), was used as an effective source of micronutrients in correcting metal deficiency in soil. From the TEM image, the morphology of the sample was spherical. It can be clearly observed that metal oxides particles were separately located on chelating agents. Nanochelated fertilizers were applied at the rate of $1 \mathrm{~kg} \mathrm{ha}^{-1}$. Urea fertilizer was utilized for nitrogen treatments as spilt application. The first split application was applied in anhydrous form as close to the plants as possible in order to minimize $\mathrm{N}$ losses. The second and third portions were applied as top-dress during the vegetative and reproductive growth stages. To avoid surface volatilization, topdressing was carried out shortly before the rains. Nano-chelated micronutrients were banded below the soil surface (subsurface banding) during planting. Plants were grown under rainfed conditions and not irrigated. Gravimetric water content $(\theta \mathrm{g})$ at 30 , 60 , and 90 days after the sowing date at a depth of $30 \mathrm{~cm}$ was $39 \%, 26 \%$, and $18 \%$, respectively.

At the maturity stage when the most of the leaves turned brown and very little green remained on the bracts of the latest flowering heads (from late June to early July), plants were manually harvested at the ground level. Data on growth characteristics and yield components were recorded on ten plants randomly selected from three middle rows. The evaluated agronomic traits included first capitula height, the number of branches per plant, stem diameter $(\mathrm{mm})$, capitula diameter $(\mathrm{mm})$, the number of capitula per plant, the number of seeds per capitula, the weight of seeds per capitula, unfilled (hollow) seeds per plant, 1000-seed weight. Plant height was evaluated from the ground level to the tip of main stem at maturity time. Biological yield was obtained by cutting the plant at ground level at maturity stage. Straw yield was calculated by subtracting seed yield from dry matter yield. The harvest index was calculated as the ratio of grain yield to aboveground dry matter at maturity.

All data were subjected to variance analysis (ANOVA) for each character to determine crop parameter response to nano-chelated micronutrients and $\mathrm{N}$ rates. Statistical analysis of the data was performed using the SAS program. The least significant difference (LSD) at $5 \%$ was used to compare between the means. Pair-wise Pearson's correlation coefficient was calculated among twenty agronomic traits. Cluster analysis was performed for the traits and treatment combinations. The principal components analysis (PCA) based on Everitt and Dunn (1992) was used.

\section{RESULTS}

Variance analysis revealed that nitrogen fertilizer significantly affected the plant height $(p \leq 0.01)$. The tallest plants were obtained by applying $75 \mathrm{~kg} \mathrm{~N} \mathrm{ha}^{-1}$. However, neither nitrogen nor nano-chelated micronutrient fertilizers could affect the first branch height and first capitulum height from the ground level (Table 1). The canopy spread was significantly affected by both fertilizer factors, and also the interaction effect of nitrogen $\times$ nano-chelated micronutrients was significant for this trait. Mean comparison of the canopy spread between different combined treatments showed that the largest canopy was recorded for plant grown with $75 \mathrm{~kg} \mathrm{~N} \mathrm{ha}^{-1}$ along with nano-chelated $\mathrm{Zn}\left(\mathrm{N}_{75}{ }^{-}\right.$ $\mathrm{Zn}$ ), which was followed by plants grown by integrated application of $150 \mathrm{~kg} \mathrm{~N} \mathrm{ha}^{-1}$ and nanochelated $\mathrm{Cu}$ (Fig. 1). Also, the interaction effects of nitrogen $\times$ nano-chelated micronutrients was statistically significant $(p \leq 0.05)$. The highest ground cover percentage was related to the plants grown by integrated application of $150 \mathrm{~kg} \mathrm{~N} \mathrm{ha}^{-1}$ and nano-chelated $\mathrm{Cu}\left(\mathrm{N}_{150}-\mathrm{Cu}\right)$ which fallowed by $\mathrm{N}_{75}-\mathrm{Zn}$ and $\mathrm{N}_{0}-\mathrm{Zn}$. However, the lowest amount of ground cover was recorded 
for plants grown with the application of $\mathrm{N}_{0}-\mathrm{Fe}$ and $\mathrm{N}_{75}-\mathrm{Cu}$. Evaluation of the stem diameter showed that both nitrogen $(p \leq 0.05)$ and nanochelated micronutrient fertilizer $(p \leq 0.01)$ affected this trait. Mean comparison of the stem diameter revealed that the thickest stem was related to the plant grown with the application of $\mathrm{N}_{75}-\mathrm{Zn}$ and $\mathrm{N}_{150}-\mathrm{Cu}$. Nitrogen application considerably $(p \leq 0.01)$ influenced plant dry weight (Table 1). Also, the interaction effect of nitrogen $\times$ nano-chelated micronutrients were significant for this character. The highest value was recorded for integrated application of $75 \mathrm{~kg} \mathrm{~N} \mathrm{ha}^{-1}$ and nano-chelated $\mathrm{Zn}$, while the lowest dry weight were related to plants grown with the application of $\mathrm{N}_{0}$-Fe.

The number of the secondary branches noticeably affected by nano-chelated micronutrients and the highest number of the secondary branches were observed in plants grown with nano-chelated $\mathrm{Zn}$ (Table 1). The assessment of the capitulum diameter revealed that the main effect of nano-chelated micronutrients and interaction effects of nitrogen $\times$ nano-chelated micronutrients was statistically significant. The largest capitulum were recorded for plants

Table 1. The effect of different levels of nitrogen and nano-chelated micronutrients on some morphological traits of safflower (Carthamus tinctorius $\mathrm{L}$.)

\begin{tabular}{|c|c|c|c|c|c|c|c|c|c|c|}
\hline Nitrogen fertilizer & $\mathrm{PH}$ & FBH & $\mathrm{FCH}$ & $\mathrm{CS}$ & GC & SD & DW & SB & MCD & $\mathrm{BY}$ \\
\hline & $* *$ & NS & NS & $* *$ & NS & * & $* *$ & NS & NS & NS \\
\hline Zero & $\begin{array}{c}49.00 \\
\mathrm{~b}\end{array}$ & $28.41 \mathrm{a}$ & $40.73 a$ & $22.10 \mathrm{~b}$ & $61.11 \mathrm{a}$ & $6.88 \mathrm{~b}$ & $29.77 b$ & $6.66 a$ & $22.55 b$ & 3181.15 \\
\hline $75 \mathrm{~kg} \mathrm{ha}^{-1}$ & $60.76 a$ & $26.26 a$ & $44.60 \mathrm{a}$ & $27.37 \mathrm{a}$ & $59.44 a$ & $7.77 \mathrm{a}$ & $35.77 \mathrm{a}$ & $7.33 a$ & $25.88 \mathrm{a}$ & 3045.00 \\
\hline $150 \mathrm{~kg} \mathrm{ha}^{-1}$ & $50.18 \mathrm{~b}$ & $29.55 a$ & $39.08 \mathrm{a}$ & $20.73 b$ & $61.33 \mathrm{a}$ & $6.77 \mathrm{~b}$ & $28.55 b$ & $6.55 \mathrm{a}$ & $22.00 \mathrm{~b}$ & $2860.17 a$ \\
\hline \multicolumn{11}{|c|}{ Nano micronutrient (M) } \\
\hline & NS & NS & NS & $* *$ & * & $* *$ & NS & * & * & NS \\
\hline $\mathrm{Fe}$ & $51.90 \mathrm{a}$ & $29.97 \mathrm{a}$ & $41.46 \mathrm{a}$ & $20.00 \mathrm{~b}$ & $56.66 \mathrm{~b}$ & $6.44 \mathrm{~b}$ & $29.56 b$ & $6.11 b$ & $21.11 \mathrm{c}$ & 2711.80 \\
\hline $\mathrm{Zn}$ & $54.44 a$ & $26.05 a$ & $40.68 \mathrm{a}$ & 25.91a & $63.88 \mathrm{a}$ & $7.55 \mathrm{a}$ & $33.88 \mathrm{a}$ & $8.00 \mathrm{a}$ & $25.77 \mathrm{a}$ & 3297.20 \\
\hline $\mathrm{Cu}$ & $53.28 \mathrm{a}$ & $28.20 \mathrm{a}$ & $42.26 \mathrm{a}$ & $24.30 \mathrm{a}$ & $61.33 \mathrm{ab}$ & $7.44 a$ & $30.66 \mathrm{ab}$ & $6.44 \mathrm{~b}$ & $23.55 b$ & $3077.25 a$ \\
\hline $\mathrm{N} \times \mathrm{M}$ & NS & NS & NS & ** & * & $* *$ & * & NS & $* *$ & * \\
\hline
\end{tabular}

PH - plant height at maturity $(\mathrm{cm}), \mathrm{FBH}-$ the first branch height $(\mathrm{cm})$, the height of the first capitulum $(\mathrm{cm}), \mathrm{CS}$ : canopy spread (cm), GC: ground cover (\%), SD - stem diameter (mm), DW - plant dry weight (g), SB - number of secondary branches, MCD - mean of capitulum diameter (mm), BY - biological yield (kg ha-1), N - nitrogen fertilizer, $M$ - micro-nutrient, NS - not significant, ${ }^{\star}$ - significant at $5 \%$ level of probability, ${ }^{\star *}$ - significant at $1 \%$ level of probability. Mean values of the same category followed by different letters are significant at $p \leq 0.05$ level.

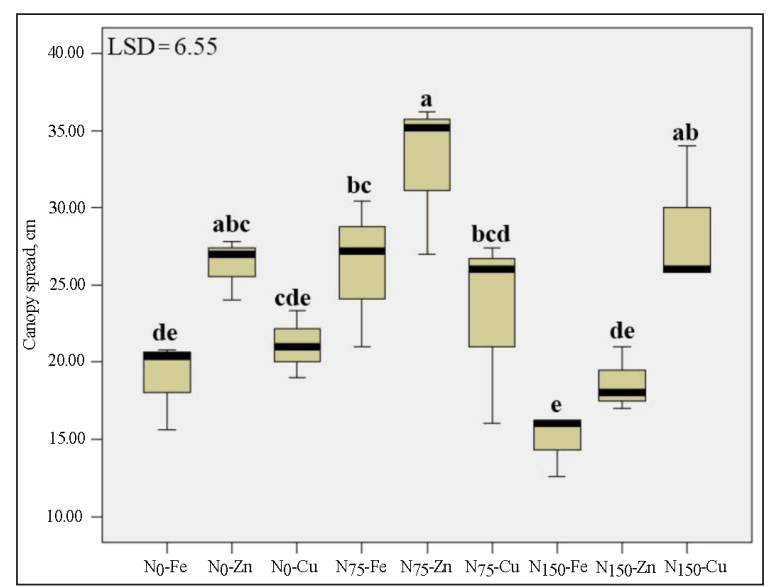

Fig. 1. The effect of combined application of nitrogen and nano-chelated micronutrients on the canopy spread in the safflower plants grown under rainfed condition in Baneh region. Vertical bars show the standard error. Values with the same letter were not significantly different 
grown with $\mathrm{N}_{75}-\mathrm{Zn}$ and $\mathrm{N}_{150}-\mathrm{Cu}$, while there was no significant difference between other treatments (Fig. 2). A comparison of combined treatments for biological yield showed that the lowest biological yield was related to the plants grown with the application of $\mathrm{N}_{150^{-}}$ $\mathrm{Fe}, \mathrm{N}_{150}-\mathrm{Zn}$, and $\mathrm{N}_{75}-\mathrm{Fe}$ (Fig. 3). Interestingly, the results showed that the consumption of

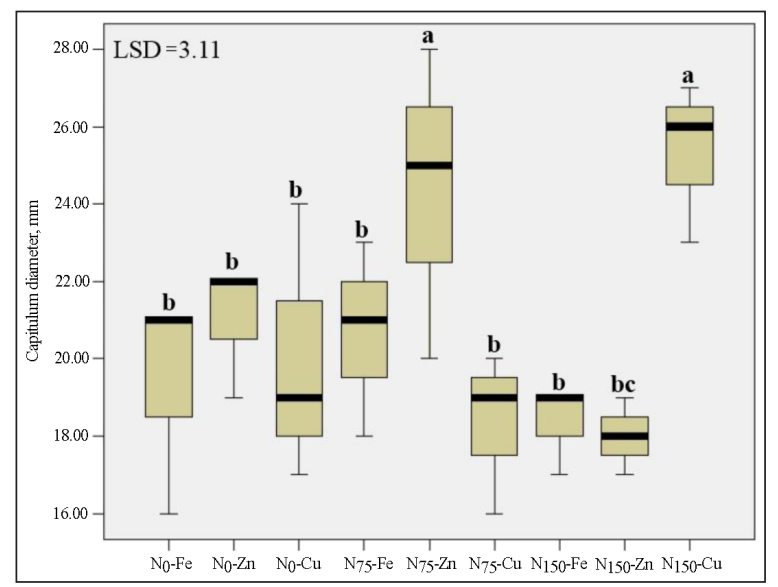

Fig. 2. The effect of different nitrogen levels and nano-chelated micronutrients on the capitulum diameter in safflower plants grown under rainfed condition in Baneh region large amounts of nitrogen along with iron and zinc could not lead to an increase of biological yield under water-limited conditions.

The number of the secondary capitulum per plant noticeably responded to micronutrients. The highest number of secondary capitula were recorded for plants grown with application of $\mathrm{Zn}$ and $\mathrm{Cu}$ (Table 2). Nitrogen application

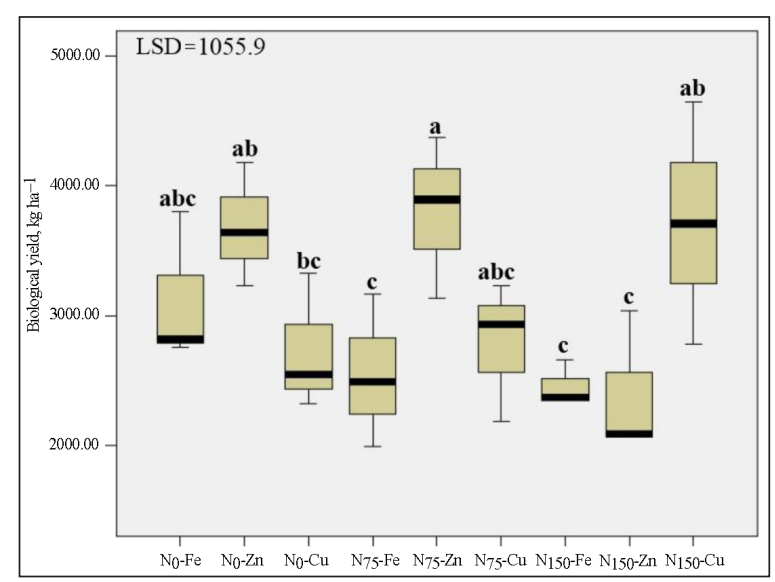

Fig. 3. The effect of different nitrogen levels and nano-chelated micronutrients on the biological yield in the safflower plants grown under rainfed condition in Baneh region

Table 2. The effect of different levels of nitrogen and nano-chelated micro-nutrients on the yield and yield components of Safflower (Carthamus tinctorius L.)

\begin{tabular}{|c|c|c|c|c|c|c|c|c|}
\hline Nitrogen fertilizer & SCN & SNP & SNS & SPP & USN & TSW & SY & $\mathrm{HI}$ \\
\hline & NS & * & NS & * & NS & NS & NS & NS \\
\hline Zero & $7.33 \mathrm{a}$ & $30.77 \mathrm{ab}$ & $21.88 \mathrm{a}$ & $187.67 \mathrm{a}$ & $6.60 \mathrm{a}$ & $35.55 \mathrm{a}$ & $922.66 \mathrm{a}$ & $29.39 \mathrm{a}$ \\
\hline $75 \mathrm{~kg} \mathrm{ha}^{-1}$ & $6.66 \mathrm{a}$ & $33.22 \mathrm{a}$ & $21.00 \mathrm{a}$ & $133.56 \mathrm{~b}$ & $7.21 \mathrm{a}$ & $35.66 \mathrm{a}$ & $879.11 \mathrm{a}$ & $30.19 \mathrm{a}$ \\
\hline \multirow[t]{3}{*}{$150 \mathrm{~kg} \mathrm{ha}^{-1}$} & $6.40 \mathrm{a}$ & $28.44 \mathrm{~b}$ & $21.22 \mathrm{a}$ & $131.89 \mathrm{~b}$ & $7.94 \mathrm{a}$ & $35.55 \mathrm{a}$ & $853.89 \mathrm{a}$ & $31.04 \mathrm{a}$ \\
\hline & \multicolumn{8}{|c|}{ Nano micro-nutrient } \\
\hline & * & NS & * & NS & * & NS & * & NS \\
\hline $\mathrm{Fe}$ & $5.22 \mathrm{~b}$ & $29.88 \mathrm{a}$ & $19.66 \mathrm{~b}$ & $144.56 \mathrm{a}$ & $7.27 \mathrm{ab}$ & $35.22 \mathrm{a}$ & $862.78 \mathrm{ab}$ & $32.88 \mathrm{a}$ \\
\hline $\mathrm{Zn}$ & $7.66 \mathrm{a}$ & $32.55 a$ & $24.68 \mathrm{a}$ & $164.22 \mathrm{a}$ & $6.01 \mathrm{a}$ & $35.77 \mathrm{a}$ & $936.11 \mathrm{a}$ & $29.02 \mathrm{a}$ \\
\hline $\mathrm{Cu}$ & $7.55 \mathrm{a}$ & $30.00 \mathrm{a}$ & $25.77 \mathrm{bc}$ & $144.33 \mathrm{a}$ & $8.47 \mathrm{a}$ & $35.31 \mathrm{a}$ & $856.78 \mathrm{~b}$ & $28.71 \mathrm{a}$ \\
\hline $\mathrm{N} \times \mathrm{M}$ & NS & NS & * & * & * & $* *$ & * & NS \\
\hline
\end{tabular}

SCN - number of secondary capitulum per plant, SNP - number of the seed in the main capitulum, SNS - seed number in the secondary capitulum, SPP - seed number in the plant, USN - percentage of unfilled seeds per plant, TSW - 1000-seed weight (g), SY - seed weight $\left(\mathrm{kg} \mathrm{ha}^{-1}\right), \mathrm{HI}$ - harvest index (\%), N - nitrogen fertilizer, $\mathrm{M}$ - micro-nutrient, NS - not significant, ${ }^{*}$ - significant at $5 \%$ level of probability, ${ }^{* *}$ - significant at $1 \%$ level of probability. Mean values of the same category followed by different letters are significant at $p \leq 0.05$ level. 
significantly affected the number of seeds in the main capitulum. Interestingly, the lowest number was recorded for plants grown with a high level of nitrogen and plants grown with $75 \mathrm{~kg} \mathrm{~N}$ showed the highest number. The effects of the interaction of nitrogen $\times$ nano-chelated micronutrients were significant for the seed number in the secondary capitulum (Table 2). Mean comparison for this trait showed that the highest value were related to plants grown with application of $\mathrm{N}_{0}-\mathrm{Zn}, \mathrm{N}_{75}-\mathrm{Zn}$ and $\mathrm{N}_{150^{-}}$ $\mathrm{Cu}$ (Fig. 4). A similar trend was observed for the seed number per plant, so that the highest value was obtained from plants grown with application of $\mathrm{N}_{0}-\mathrm{Zn}$. The main effect of

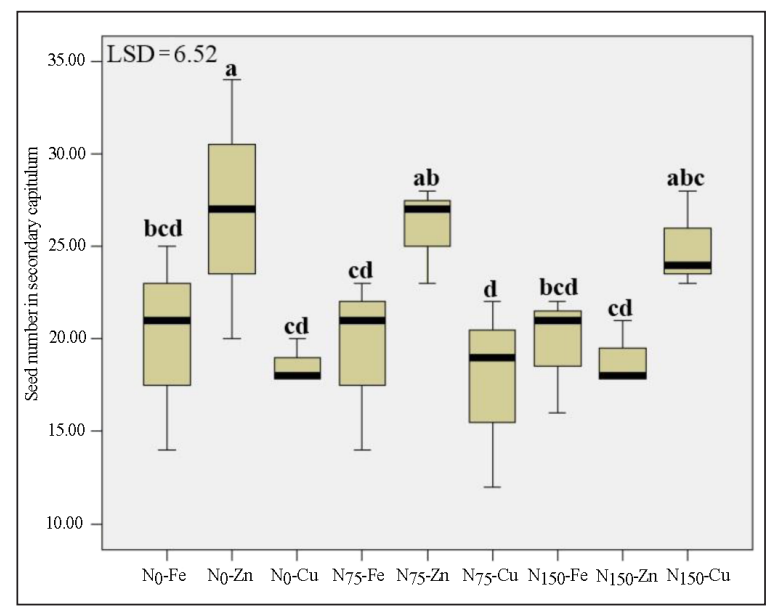

Fig. 4. The effect of combined application of nitrogen and nano-chelated micronutrients on the seed number in the secondary capitulum of the safflower plants grown under rainfed conditions in Baneh region

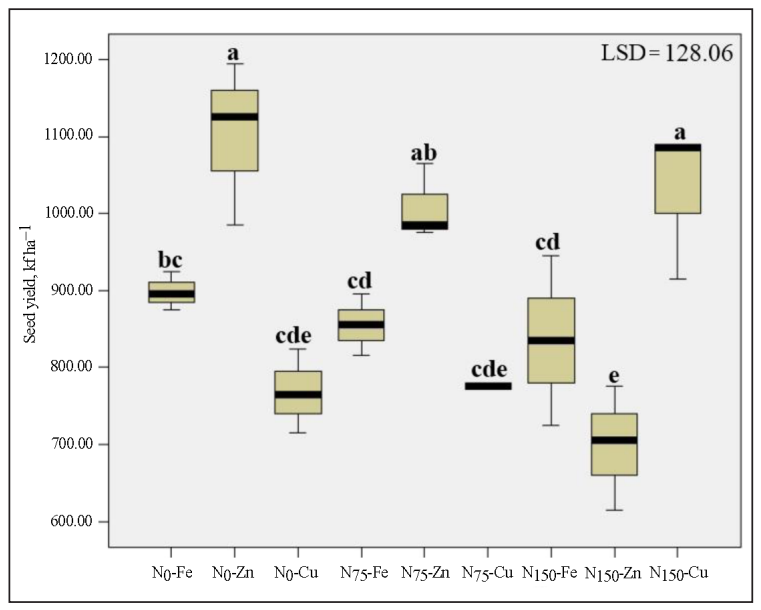

nano-chelated micronutrients and the effect of the interaction of nitrogen $\times$ nano-chelated micronutrients were statistically significant for the percentage of unfilled seed (Table 2). The lowest amount of unfilled seeds were recorded in the plants grown with application of $\mathrm{N}_{0}-\mathrm{Zn}$ and $\mathrm{N}_{75}-\mathrm{Zn}$. Evaluation of the 1000seed weight between the combined treatments revealed that the heaviest seeds came from the plants grown with application of $\mathrm{N}_{75}-\mathrm{Zn}$ and $\mathrm{N}_{150}$ - Cu (Fig. 5). The effect of the interaction of nitrogen $\times$ nano-chelated micronutrients was significant for the seed yield, and the highest yield was recorded for plants grown with application of $\mathrm{N}_{0}-\mathrm{Zn}, \mathrm{N}_{75}-\mathrm{Zn}$ and $\mathrm{N}_{150}-\mathrm{Cu}$ (Fig. 6).

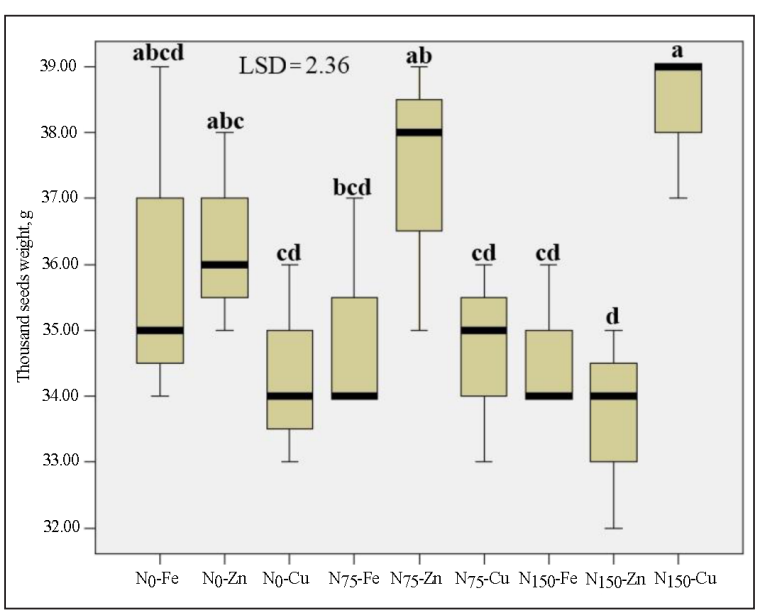

Fig. 5. The effect of different nitrogen levels and nano-chelated micronutrients on 1000-seed weight of the safflower plants grown under rainfed condition in Baneh region

Fig. 6. The effect of combined application of nitrogen and nano-chelated micronutrients on seeds of the safflower plants grown under rainfed condition in Baneh region 


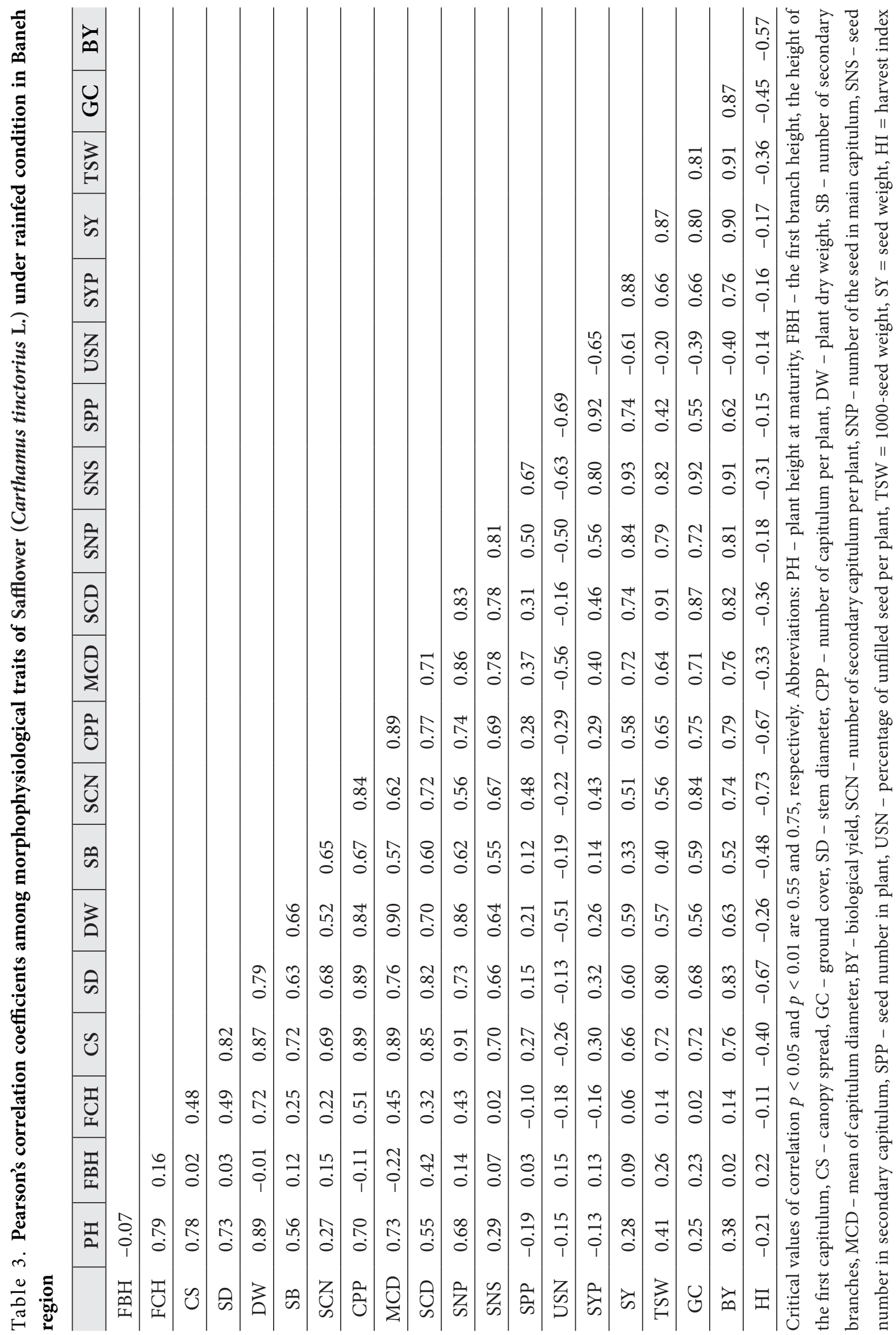


The correlation coefficient between the seed yield and other morpho-physiological traits are presented in Table 3. In this study, highly significant positive and negative correlations were obtained. The highest correlation coefficient was found between the canopy spread and the stem diameter, plant dry weight, the number of secondary branches, the number of capitula per plant, capitulum diameter, seed number in capitulum, 1000-seed weight, and the biological yield. A negative correlation was observed between the percentage of unfilled seeds and yield components. There was a significant positive correlation between seed yield and capitulum diameter, seed number in the secondary capitulum, ground cover percentage, thousand seeds weight and biological yield. A similar status was also reported by Mahasi et al. (2006), Janmohammadi (2015), and Shahrokhnia and Sepaskhah (2017).

Cluster analysis of agronomic and morphophysiological traits divided them into three

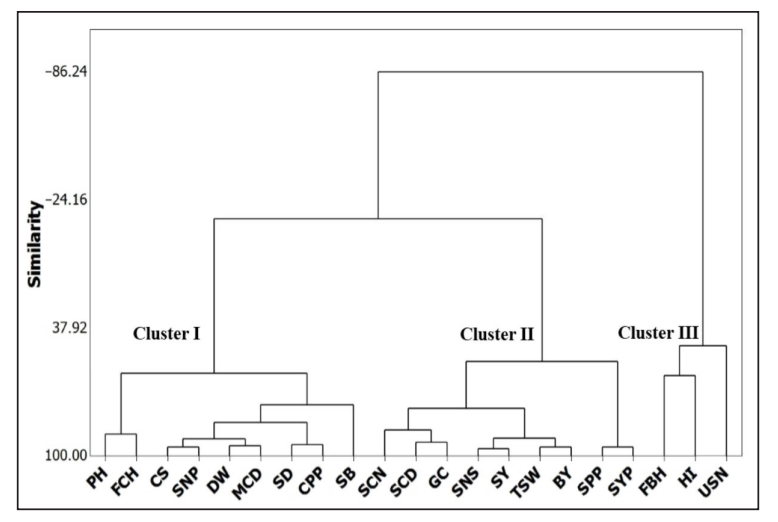

Fig. 7. Cluster analysis of agronomic and morphophysiological traits in safflower (Carthamus tinctorius L.) under rainfed condition in Baneh region. $\mathrm{PH}$ - plant height at maturity, FBH - the first branch height, the height of the first capitulum, CS - canopy spread, GC - ground cover, SD - stem diameter, CPP - number of capitulum per plant, DW - plant dry weight, SB - number of secondary branches, mean of capitulum diameter, BY - biological yield, SCN = number of secondary capitulum per plant, SNP - number of the seed in main capitulum, SNS - seed number in secondary capitulum, SPP - seed number in plant, USN - percentage of unfilled seed per plant, TSW - 1000-seed weight, SY - seed weight, HI - harvest index groups according to the similarity of the response to fertilizer treatments (Fig. 7). The first cluster included the plant height, the first capitulum height, the canopy spread, the number of seeds in the main capitulum, dry weight, the diameter of the main capitulum, stem diameter, the number of the capitulum per plant, and the number of secondary branches. In this group, the best performance was observed with application of $\mathrm{N}_{75}-\mathrm{Zn}$, and the lowest value was recorded with application of $\mathrm{N}_{0}-\mathrm{Fe}$ and $\mathrm{N}_{150}-\mathrm{Zn}$. The second cluster included the number of the secondary capitulum, the diameter of the secondary capitulum, ground cover, the number of seeds in the secondary capitulum, seed yield, 1000seed weight, and the biological yield (Fig. 7). In this group, the highest value was obtained with application of N0-Zn, $\mathrm{N}_{75}-\mathrm{Zn}$ and $\mathrm{N}_{150}-\mathrm{Cu}$. The third cluster included the first branch height, the harvest index, and the unfilled seed percentage, the lowest amount of which was recorded with application of $\mathrm{N}_{0}-\mathrm{Zn}$. Also, cluster analysis of combined treatments regarding the effect of treatments on the morpho-physiological traits divided the treatments into three cluster. Cluster I included $\mathrm{N}_{0}-\mathrm{Fe}, \mathrm{N}_{0}-\mathrm{Cu}$, and $\mathrm{N}_{75}-\mathrm{Cu}$, which had no prominent effects. Cluster II included $\mathrm{N}_{75}-\mathrm{Fe}, \mathrm{N}_{150}-\mathrm{Fe}$, and $\mathrm{N}_{150}-\mathrm{Zn}$, with the application which the lowest value for most traits was recorded. Cluster III included $\mathrm{N}_{0}-\mathrm{Zn}, \mathrm{N}_{75}-\mathrm{Zn}$, and $\mathrm{N}_{150}-\mathrm{Cu}$, through which approximately the best performance was achieved (Fig. 8).

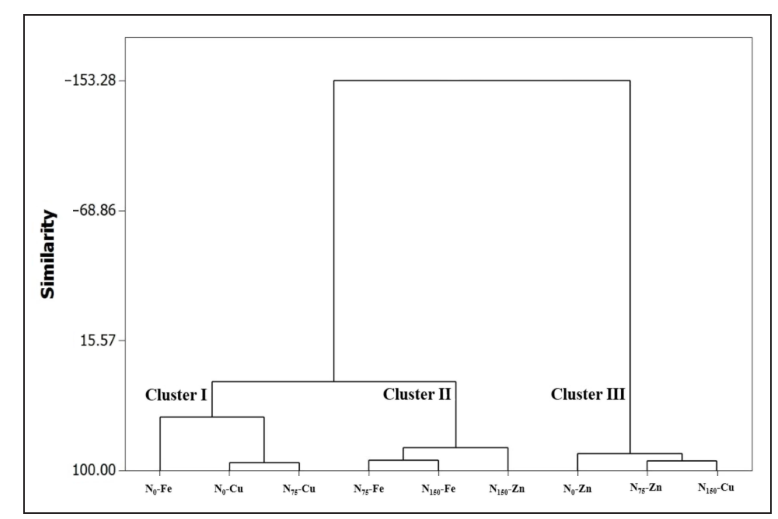

Fig. 8. Grouping of different combined treatments of nitrogen and micronutrient fertilizer in terms of similarities in influencing the growth and yield of safflower 


\section{DISCUSSION}

Our findings revealed that application of medium levels of nitrogen apparently improved the morphological traits and crop growth parameters. However, there was no significant difference between control (no nitrogen application) and $150 \mathrm{~kg} \mathrm{Nha}^{-1}$. This finding supports previous research that reported that soils in the highlands area in the west of Iran are usually low in nitrogen and organic carbon content (less than $0.6 \%$ ) and generally need basal or topdressing application of $\mathrm{N}$-fertilizer for viable and economic agricultural production (Roozitalab et al., 2011). With regard to structural and functional roles of nitrogen, improved growth with nitrogen application seems to be reasonable. Nitrogen-containing compounds such as protein, nucleic acid, chlorophyll, and functional enzymes are very important in the biochemical process (Marschner, 2012). It is encouraging to compare this figure with that found by Zareie et al., (2011), who found that application of $100 \mathrm{~kg} \mathrm{~N} \mathrm{ha}^{-1}$ along with foliar application of iron sulfate (2000 ppm) was a useful combination treatment and significantly improved the seed yield of safflower genotypes in semi-arid region. It seems necessary to remind that crop production in semi-arid areas is constrained by soil deficiencies in moisture and plant nutrients (particularly nitrogen and micronutrients). Therefore, sufficient levels of irrigation and nitrogen are required to secure acceptable yields. However, the results showed that application of $150 \mathrm{~kg} \mathrm{~N} \mathrm{ha}^{-1}$ could not improve the growth-related characteristics. In this regard it has been suggested that under water-limited conditions, increased nitrogen utilization will induce rapid plant growth during the vegetative period which will enhance the rate of evapotranspiration and the depletion of limited soil moisture reserves, and, consequently, result in decreased dry matter production (Ali et al., 2005). Nonetheless, safflower is still a suitable crop for the semi-arid region, because the deep root system of safflower helps to extract the water and nutrients from much deeper layers of soil compared to other crop plants and thus makes it an ideal crop for rain-fed cropping systems (Singh,
Nimbkar, 2006). The goal of suitable nitrogen management is to enhance the efficiency of nitrogen use; currently, values in the Mediterranean semi-arid rainfed area range from $20 \%$ to $70 \%$. The findings showed that the efficiency and effectiveness of medium level of nitrogen was more prominent than that of high level.

The results also revealed that safflower plants noticeably responded to nano-chelated micronutrient. The best growth performance and the highest yield were recorded for plants grown with nano-chelated zinc and copper fertilizers. Zinc is a fundamental component of many functional enzymes and structural proteins. It plays an imperative role in a wide range of processes, such as stabilizing RNA and DNA structures, in maintaining the activity of DNA synthesizing enzymes, controlling the activity of RNA degrading enzymes, growth hormone production (auxin), and internode elongation (Alloway, 2008). This element is also necessary for the synthesis of chlorophyll and some carbohydrates and for conversion of starches to sugars (Hänsch, Mendel, 2009). Furthermore, Zn application can show a synergistic influence on uptake of other micronutrient cations at flowering stage of the crop (Suresh et al., 2013). Copper also participates in numerous physiological processes and it is an essential metal for normal plant growth and development. At the cellular level, it has critical roles in signaling of transcription and protein trafficking machinery, oxidative phosphorylation (Yruela, 2005; Hänsch, Mendel, 2009).

It is well recognized that the acceptable plant growth and optimum crop yield depends not only on the total amount of nutrients present in the soil at a particular time, but also on their availability which in turn is controlled by such physico-chemical characteristics as soil texture, organic carbon and calcium carbonate, cation exchange capacity, $\mathrm{pH}$, and electrical conductivity of soil (Bell, Dell 2008; Kumar, Babel, 2011). In semi-arid soils the mentioned properties are insufficient. Furthermore, the interaction between nitrogen and micronutrients occurs frequently, and mostly synergistically, in crops (Monreal et al., 2015). Increasing the rates of 
nitrogen fertilizer and micronutrients $(\mathrm{Zn}, \mathrm{Cu}$, $\mathrm{Mn}, \mathrm{Fe}, \mathrm{Mo}$, and $\mathrm{B}$ ) added in combination to a silty loam soil resulted in significant grain yield increases of rice under well-watered conditions (Roshan et al., 2011). Our results revealed that under rain-fed conditions the interaction trend based on the amount of nitrogen application may be somewhat different. In general, the interaction between nitrogen and micronutrients stimulate plant growth. However, such stimulation may cause micronutrients deficiency under a limited supply of the microelements in soils (Fageria, 2001). The present findings seem to be consistent with conclusions of other studies which showed that integrated application of nitrogen and micronutrients significantly increased micronutrient efficiency (Monreal et al., 2015). Among the yield components, 1000-seed weight (TWS) was not influenced by nitrogen and micronutrients. Similarly, Shahrokhnia and Sepaskhah (2017) found that among the yield components, TWS did not show a significant response to nitrogen fertilizer. In general, application of irrigation strategies, planting methods, and $\mathrm{N}$ fertilization showed minor influences on TSW in safflower. Indeed, the harvest index of safflower was stable across fertilizer treatments that is in agreement with the results reported by Shahrokhnia and Sepaskhah (2017).

The novelty of this experiment was the application of nano-chelated micronutrients. With nanotechnology, micronutrients can be produced in the nano-size range, with the advantage of initial fast release of plant-usable ions at application, and then a more sustained slow release over time (Ranjan et al., 2016). Principally, this status can result in reduced ionic losses relative to conventional fertilizers, but increased availability during plants growth relative to bulk particles. The findings highlighted that macronutrient fertilizers of $\mathrm{N}$ and nano-chelated fertilizers of $\mathrm{Zn}$ and $\mathrm{Cu}$ could have significant effects on growth and yield of safflower. Integrated application of nitrogen and micronutrients can result in more uniform seedling emergence, higher ground cover by canopy, increased fertilizer efficiency, and a higher seed yield.

\section{CONCLUSIONS}

Our findings revealed that nitrogen deficiency is one the major limiting factors in the evaluated region. The efficiency of micronutrients, especially zinc and copper, significantly depended on the availability of nitrogen. The lowest efficiency was observed for nano-chelated iron. The present investigation concluded that under no-nitrogen application conditions there was little difference between micronutrients. However, results showed that safflower can be successfully produced in a highland region with precise medium fertilizer input. An evaluation of growth and yield parameters revealed that the most effective micronutrients were zinc and copper. The findings of this study showed that nano-chelated micronutrient fertilizer with smart delivery systems which can react to environmental changes could be a suitable option to overcome the micronutrient deficiencies in semi-arid regions. However, the efficiency and effectiveness of nano-chelated fertilizer is strongly influenced by availability and abundance of macronutrients. The findings of the current study showed that there were obvious simplifications in the concept of nutrient interactions and this was greatly influenced by other environmental factors such as water availability. The results highlighted the need for low rates of fertilizer $\mathrm{N}$ application along with nanochelated zinc to optimize spring safflower yields. Overall, the environmental benefits of nanofertilizers in the rainfed area will be realized only when a balanced nutrient management is designed. Future research should therefore aim at evaluation of the interaction of nano-chelated micronutrients and macronutrients with different levels of consumption under different soil moisture conditions.

\section{ACKNOWLEDGEMENTS}

The authors are grateful for financial support from the University of Maragheh. We would like to thank Bahram Mazani (representative of Sepehr Parmis) for the supply of nano-fertilizers. We also thank Mojtaba Amini and appreciate constructive discussions about the properties 
of nanostructured nano-fertilizers. We wish to thank all those who contributed, collaborated, or technically supported us during the field experiment.

Received 30 April 2017 Accepted 1 February 2018

\section{References}

1. Ali ZI, Dawelbeit SE, Salih AA. Effect of water stress and nitrogen application on grain yield of wheat. Agron J. 2005; 80: 902-8.

2. Alloway BJ. Zinc in soils and crop nutrition (2nd edition). Brussels: International Zinc Association; 2008. p. 135.

3. Bell RW, Dell B. Micronutrients for sustainable food, feed, fiber and bioenergy production. 1st edition. Paris: International Fertilizer Industry Association (IFA); 2008.

4. DeRosa MC, Monreal C, Schnitzer M, Walsh R, Sultan Y. Nanotechnology in fertilizers. Nature nanotechnology 2010; 5(2): 91-1.

5. Dimkpa CO, Bindraban PS. Fortification of micronutrients for efficient agronomic production: a review. Agron Sustain Dev. 2016; 36(1): $1-26$.

6. Everitt BS, Dunn G. Applied multivariate data analysis. New York: Oxford University Press; 1992.

7. Fageria VD. Nutrient interactions in crop plants. J Plant Nutr. 2001; 24(8): 1269-90.

8. FAO. 1998. Management of nutrients and water in rainfed arid and semi-arid areas. Proceedings of a consultants meeting (No. IAEATECDOC-1026). Joint FAO/IAEA Division of Nuclear Techniques in Food and Agriculture.

9. FAO. 2015. Crop Water Information: Safflower. [cited 2016 Dec 7]. Available from: <http:// www.fao.org/nr/water/cropinfo_safflower. html>.

10. FAOSTAT. 2013. World production of safflower seeds in 2013; Browse Production/Crops/ World". United Nations Food and Agriculture Organization, Statistics Division.
11. Haghighati Malek A, Ferri F. Effects of nitrogen and phosphorus fertilizers on safflower yield in dry lands condition. Int J Res Agri Sci. 2014; 1: 28-33.

12. Hänsch R, Mendel RR. Physiological functions of mineral micronutrients $(\mathrm{Cu}, \mathrm{Zn}, \mathrm{Mn}, \mathrm{Fe}, \mathrm{Ni}$, Mo, B, Cl). Curr Opin Plant Biol. 2009; 12(3): 259-66.

13. Janmohammadi M, Sabaghnia N, Nouraein M, Dashti S. Responses of potato (Solanum tuberosum L.) var. Agria to application of bio, bulk and nano-fertilizers. Annales Universitatis Mariae Curie-Sklodowska, sectio C-Biologia 2015; 70(2): 57-66.

14. Janmohammadi M. Evaluation of the impact of chemical and biological fertiliser application on agronomical traits of safflower (Carthamus tinctorius L.). Proceedings of the Latvian Academy of Sciences. Section B. Natural, Exact, and Applied Sciences 2015; 69(6): 331-5.

15. Kumar M, Babel AL. Available micronutrient status and their relationship with soil properties of Jhunjhunu Tehsil, District Jhunjhunu, Rajasthan, India. J Agr Sci. 2011; 3(2): 97106.

16. Kumar P, Sharma MK. Nutrient deficiencies of field crops: guide to diagnosis and management. In Nutrient deficiencies in oilseed crops: Safflower (Carthamus tinctorius L.). CABI, Wallingford, England. 2013.

17. Mahasi MJ, Pathak RS, Wachira FN, Riungu TC, Kinyua MG, Kamundia JW. Correlations and path coefficient analysis in exotic safflower (Carthamus tinctorious L.) genotypes tested in the arid and semi-arid lands (Asals) of Kenya. Asian Journal of Plant Sciences. 2006; 5(6): 1035-8.

18. Marschner P. Marschner's mineral nutrition of higher plants, 3rd edition. San Diego: Academic Press; 2012.

19. Mastronardi E, Tsae P, Zhang X, Monreal C, DeRosa MC. Strategic role of nanotechnology in fertilizers: potential and limitations. In: Nanotechnologies in Food and Agriculture (pp. 2-67). Cham: Springer International Publishing, 2015. 
20. Monreal CM, DeRosa M, Mallubhotla SC, Bindraban PS, Dimkpa C. The application of nanotechnology for micronutrients in soilplant systems. VFRC Report 2015/3. Washington, D.C.: Virtual Fertilizer Research Center; 2015. p. 44.

21. Mzezewa J, Misi T, Van Rensburg LD. Characterisation of rainfall at a semi-arid ecotope in the Limpopo Province (South Africa) and its implications for sustainable crop production. Water SA 2010; 36(1): 19-26.

22. Naderi MR, Danesh-Shahraki A. Nanofertilizers and their roles in sustainable agriculture. Intl J Agri Crop Sci. 2013; 5(19): 2229-32.

23. Ranjan S, Dasgupta N, Lichtfouse E. In: Nanoscience in food and agriculture. 2. Sustainable agriculture reviews. Cham: Springer; 2016.

24. Reynolds M, Foulkes MJ, Slafer GA, Berry P, Parry MA, Snape JW, Angus WJ. 2009. Raising yield potential in wheat. J Exp Bot. erp016.

25. Roozitalab MH, Serghini H, Keshavarz A, Eser V, De-Pauw E. 2011. Sustainable agricultural development of highlands in central, West Asia and North Africa. Synthesis of Regional Expert Meeting on Highland Agriculture, Karaj, Iran.

26. Roshan NM, Maral Moradi EA. Study effects of different nitrogen and micronutrients fertilizers rates. World Appli Sci J. 2011; 13(3): 419-23.

27. Ryan J. Crop nutrients for sustainable agricultural production in the drought-stressed Mediterranean region. J Agri Sci Tech. 2010; 10: 295-306.

28. Shahrokhnia MH, Sepaskhah AR. Physiologic and agronomic traits in safflower under various irrigation strategies, planting methods and nitrogen fertilization. Ind Crops Prod. 2017; 95: 126-39.

29. Singh BB, Matsui T. Cowpea varieties for drought tolerance, challenges and opportunities for enhancing sustainable cowpea production. Euphytica 2002; 167: 287-300.

30. Singh V, Nimbkar N. Safflower (Carthamus tinctorius L.). In: Singh RJ, editor. Genetic resources, chromosome engineering, and crop improvement: vegetable crops (Vol. 3). CRC press; 2006. p. 167-94.

31. Subramanian KS, Manikandan A, Thirunavukkarasu M, Rahale CS. Nano-fertilizers for balanced crop nutrition. In: Nanotechnologies in Food and Agriculture. Cham: Springer International Publishing; 2015. p. 69-80.

32. Suresh G, Murthy IY, Sudhakara Babu SN, Varaprasad KS. An overview of $\mathrm{Zn}$ use and its management in oilseed crops. Journal of SAT Agricultural Research. 2013; 11:1-11.

33. Tilahun $\mathrm{K}$. The characterisation of rainfall in the arid and semi-arid regions of Ethiopia. Water SA, 2006; 32(3): 429-36.

34. Yau SK. Winter versus spring sowing of rainfed safflower in a semi-arid, high-elevation Mediterranean environment. Eur J Agr. 2007; 26(3): 249-56.

35. Yruela I. Copper in plants. Braz J Plant Physiol. 2005; 17(1): 145-56.

36. Zareie S, Golkar P, Mohammadi-Nejad G. Effect of nitrogen and iron fertilizers on seed yield and yield components of safflower genotypes. Afr J Agr Res. 2011; 6(16): 3924-9.

\section{Mostafa Fattahi, Mohsen Janmohammadi,} Ahmad Aghaei, Naser Sabaghnia

\section{AZOTO IR NANOMIKROELEMENTŲ PO- VEIKIS DAŽINIO DYGMINO AUGIMUI RIBOTO VANDENS KIEKIO AUKŠTUMOSE SĄLYGOMIS}

\section{Santrauka}

Pagrindinis sparčiai besivystančių nanotechnologijų bruožas yra naudingosios nanodalelès. Nanotrąšos gali iš esmés pagerinti augalų maistinių medžiagų ỉsisavinimą nepalankiomis aplinkos sąlygomis. Norint ịvertinti skirtingo azoto trąšų $(0,75$ ir $150 \mathrm{~kg} / \mathrm{ha}$ ) kieko ir nanostruktūruotų mikroelementų $(\mathrm{Zn}, \mathrm{Fe}, \mathrm{Cu})$ poveikị dažinio dygmino sèklų daigumui, buvo atliktas tyrimas kalnuotame Baneh regione (Irakas). Siekta įvertinti kompleksinį nanochelatinių mikroelementų ir azoto poveikị dažiniam dygminui lietaus sąlygomis. Morfologinès savybès 
atskleidè, jog naudojant $75 \mathrm{~kg} / \mathrm{ha}$ azoto reikšmingai padidèjo augalo aukštis, lajos plotas, koto diametras ir augalo sausasis svoris. Didžiausios šių parametrų vertès nustatytos, kai augalai buvo auginami ịterpus cinko ir vario. Rezultatai rodo, jog azoto ir mikroelementų sąveika buvo reikšminga sèklų skaičiui ir svoriui. Geriausias augalų derlingumas nustatytas patręšus kompleksinemis $\mathrm{N}_{0}-\mathrm{Zn}, \mathrm{N}_{75}-\mathrm{Zn}$ ir $\mathrm{N}_{150}-\mathrm{Cu}$ trąšomis. Gauti rezultatai patvirtina, azoto poveikị mikroelementų įsisavinimui. Vidutinis azoto trąšų kiekis kartu su nanochelatiniu cinku gali pagerinti dažinio dygmino dygimą lietaus sąlygomis.

Raktažodžiai: pasèlių produktyvumas, sausumos sąlygos, aktyvūs nanoingredientai, nanostruktūrinès trąšos, maistinių medžiagų sąveika 